\title{
ANTHROPOMETRIC MEASURES IMPORTANT FOR CONTROL PANEL DESIGN IN LOCOMOTIVE OR RAILCAR
}

\author{
Davor Sumpor, Dragutin Taboršak, Jasna Jurum-Kipke
}

Original scientific paper

Frequently used commands on the locomotive or railcar control panel need to be arranged mainly within the normal reach of the arm, using multi-purpose controllers for serving several important and frequently used functions by one hand, whenever possible. From the measured anthropometric measures in the central $90 \%$ from the sufficient and random sample of 50 engine drivers the range of normal and maximal reach of arm has been defined using statistical methods for the entire population in Croatia. The ranges of statistical anthrompometric measures of the engine drivers are the constitutional factors from the group "human factor", and according to Fuller TCI model "task requirement - driver's capability" affect the difficulty of the task during driving. The correlation dependence of lumbar moment $M_{1}$ on the index of mass $B M I$ has been proven in the hypothetically most unfavourable statistical seating working position, and based on the really measured statistical anthropometric measures.

Keywords: anthropometric measures; central $90 \%$; engine drivers; human factor; normal and maximal reach of arm; task difficulty

\section{Antropomjere bitne za dizajn upravljačke ploče u lokomotivi ili motornoj garnituri}

Izvorni znanstveni članak

Često korištene komande na upravljačkoj ploči lokomotive ili motorne garniture potrebno je rasporediti pretežito unutar normalnog dosega ruku, uz korištenje višenamjenskih kontrolera za posluživanje više bitnih i često korištenih funkcija jednom rukom, kada god je to moguće. Iz izmjerenih antropomjera u središnjih 90 \% od dovoljnog i slučajnog uzorka od 50 strojovođa statističkim metodama definiran je raspon normalnog i maksimalnog dosega ruku za cijelu populaciju u RH. Rasponi statičkih antropomjera strojovođa su konstitucijski čimbenici iz grupe "ljudskog faktora", a prema Fullerovom TCI modelu "zahtjev zadaće-sposobnost vozača" utječu na težinu zadaće tijekom vožnje. Dokazana je korelacijska ovisnost lumbalnog momenta $M_{1}$ o indeksu tjelesne mase ITM u hipotetski najnepovoljnijem statičkom sjedećem radnom položaju, a na temelju stvarno izmjerenih statičkih antropomjera.

Ključne riječi: antropomjere; ljudski faktor; normalni i maksimalni doseg ruku; središnjih 90 \%; strojovođe; težina zadaće

\section{Introduction}

Already in 1985 during research [1] as part of the "Drive" project of the European Economic Community Michon considered that there was delay in the cognitive in relation to behaviourist approach to the study of behaviour and reaction of drivers. According to Näätänen and Summala [2] the emotional responses of road vehicle drivers such as insecurity, surprise and irritability can be related to various traffic situations. Näätänen and Summala [2] were among the first who determined that the statistically objective risk is no guideline for the driver's behaviour. The feeling of risk can change the driver's decision-making, and according to Taylor [3] this is emotional response of the driver to the threat due to the risk of collision. According to the more recent general theories of driver's behaviour, like Fuller's TCI model from 2005 [4], the subjective feeling of risk, instead of referring to the risk of collision, refers to the difficulty of the driving task.

The difficulty of the driving task is likened by a great majority of authors with workload. The open dynamic Fuller TCI model of "task demand - driver's capability" interface is applicable regarding engineering, since input variables include three standard groups of factors common for research of the scientific field of technology of traffic and transport: "traffic environment" abbreviated TE, "transport means" abbr. TM and "human factor" abbr. H. According to Fig. 1, when the driver's capability exceeds the task demand $(C>D)$, the task is easy. When the driver's capability and the task demand are equal $(C=D)$, the driver acts on the borders of his capability and the task is very difficult, and only at that moment the subjective risk becomes equal to the objective statistical risk. When the driver's capability is lower than the task demand $(\mathrm{C}<\mathrm{D})$, then the task is per definition simply too difficult and the driver cannot handle it, and therefore the consequence is loss of control of the vehicle, if there was no system to assist the driver or ITS.

After traffic accidents, during classical behaviourist approach to the study of statistical objective risk, based on depth studies of damaged vehicles, place of accident and participants, the groups of experts classify the factors of traffic accidents according to their shares into three standard groups of factors. In 1982 [5] Rumar by summing two long-year and independent studies of Road Research Laboratories in Great Britain and the USA with highly matching results, found extreme domination of the factors from the group "human factor" with a share of 95 $\%$ in Great Britain and $94 \%$ in the USA.

According to Fuller [4] the task demand does not depend on its complexity, and the model in Figure 1 is applicable, with an upgrade, also to the engine drivers according to Fig. 2. The engine drivers' task demand depends dominantly on the change of speed, unlike road vehicle drivers who can at the same time change both gears and direction. Fuller [4], as well as the majority of scientists after 2000 recognized the fact that the choice of speed is the primary solution of the problem of keeping the difficulty of the task within the selected limits, and the limits are subject to the motivation influences.

According to models in Figures 1 and 2, the driver's capability and the task demand are dominantly and concurrently determined by the factors from the group "human factor". The factors of "human factor" are also the factors resulting from the constitutional characteristics 
of humans, including also the ranges of characteristic anthropometric measures for a sufficient and random sample of respondents from the entire population of engine drivers in Croatia.

If at "task demand" the factors from the group "human factor" according to Figs. 1 and 2 dominantly affect the driver's choice of speed, this confirms the wellfoundedness of the hypothesis that the "task demand" will be significantly affected also by the range of anthropometric measures of engine drivers from the entire population of engine drivers in Croatia, in interaction with the arrangement and the accessibility of the frequently used commands to change the speed on the control panel, such as multipurpose controllers for manual serving of the braking module and/or accelerator module.

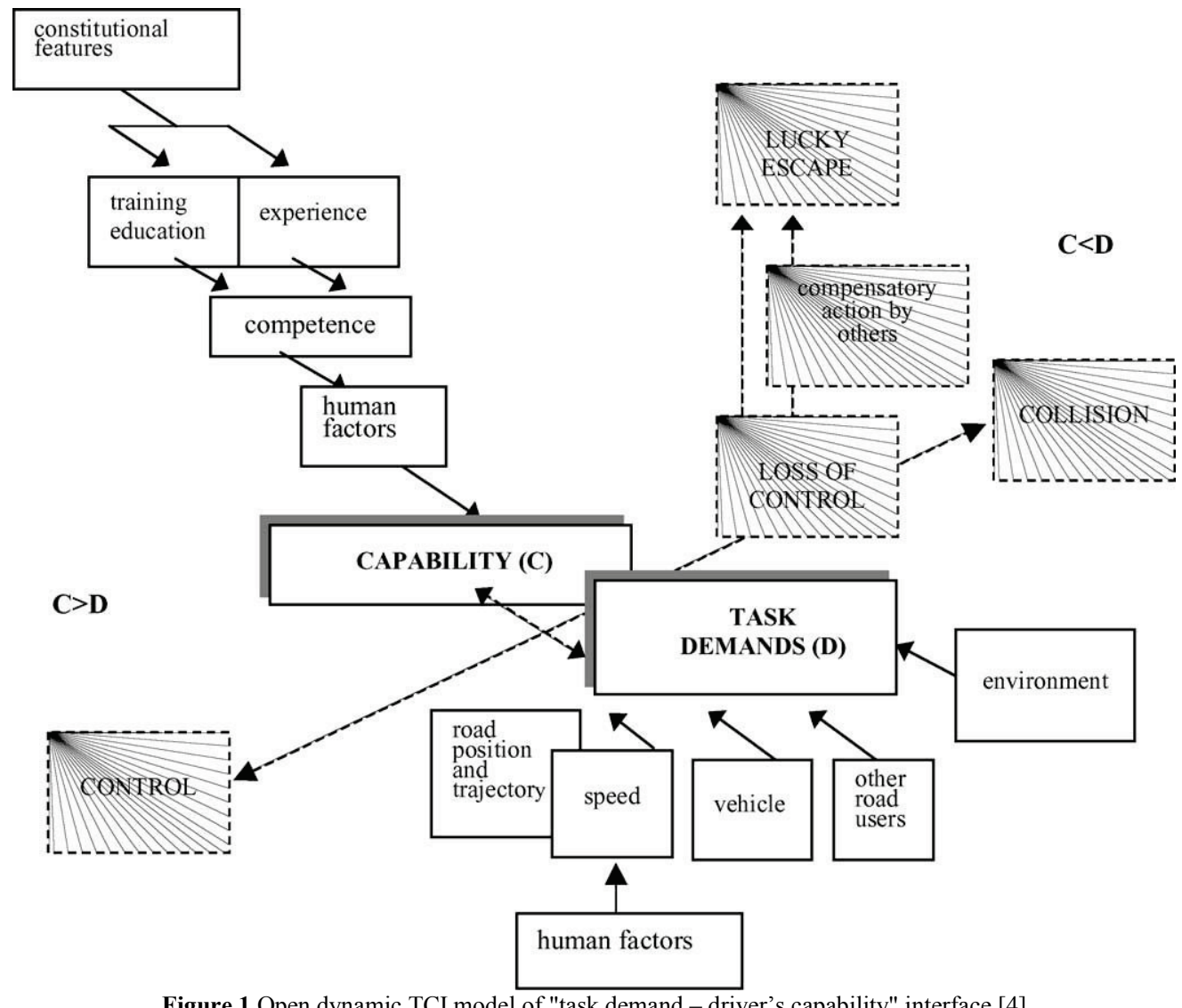

The 2012 doctoral dissertation [6] proved the influence of the "transport means" and the "traffic environment" on the group of factors "human factor", by recognizing the research results from cognitive perception of engine drivers as relevant feedback, which is in scientific literature the measure for the difficulty of the driving task. Thus, instead of the traffic accidents factors which define the statistically objective risk, the factors of ergo-assessment are taken for input data into the model, since they are factors of subjective disturbance from the cognitive perception of the engine drivers [6]. In the papers from 2009 [7] and 2010 [8] which precede the 2012 Doctoral dissertation [6], Sumpor and co-authors developed the methodology of ergonomic assessment based on the difficulty of the task, with concurrent recognition of the cognitive and behaviouristic approach to research. In the system of several concurrent factors the dominant, important and negligible factors are located [6, $7,8]$, whose individual influence relatively in relation to all the other factors is evaluated using the parameters with numerical amounts.

The factors of subjective disturbance from the cognitive perception of the engine driver can also be excessive body mass $m$ in relation to the height of the engine driver $h$ expressed by the amount of the body mass index $(B M I)$ according to formula (1), as well as inadequate design of the driver cab, control panel and seats not matching the scope of anthropometric measures of the engine drivers. The $B M I$ is an important ergonomic assessment parameter since it contains two most important statistical anthropometric measures, the standing height $h$ and the body mass $m$.

$B M I=\frac{m}{h^{2}}$

As many as $82 \%$ of the 50 surveyed engine drivers from a random sample are overweight or obese [6] regarding the numerical value of the body mass index $B M I$ ( $B M I \geq 25)$. The studies carried out during 2011 in Slovenia [9] targeting 245 employees at the railways indicate $66,9 \%$ overweight or obese workers, with no significant differences between the two groups of workers regarding the nature of their work (white or blue-collar workers).

The functional dependence of the lumbar moment in case of engine drivers $M_{1 y}=M_{1 y}(B M I)$ at the level of vertebra L4/L5 on the body mass index $B M I$, can be 
expressed as a parameter for evaluating the physical effort, which is one of the hypotheses and subject of more detailed ergo-assessment in this paper.

Instead of calculating for $n=50$ random respondents from the sample the lengths of body segments $h_{i}$ from the standing height $h$ using harmonic analyses by Muftic and
Zerderbauer $[6,10]$, the improved accuracy of calculation in this paper will be realized by regression function $M_{1 y}=$ $M_{1 y}(B M I)$ obtained on the basis of actually measured lengths of body segments $h_{i}$ outside the balance seating position.

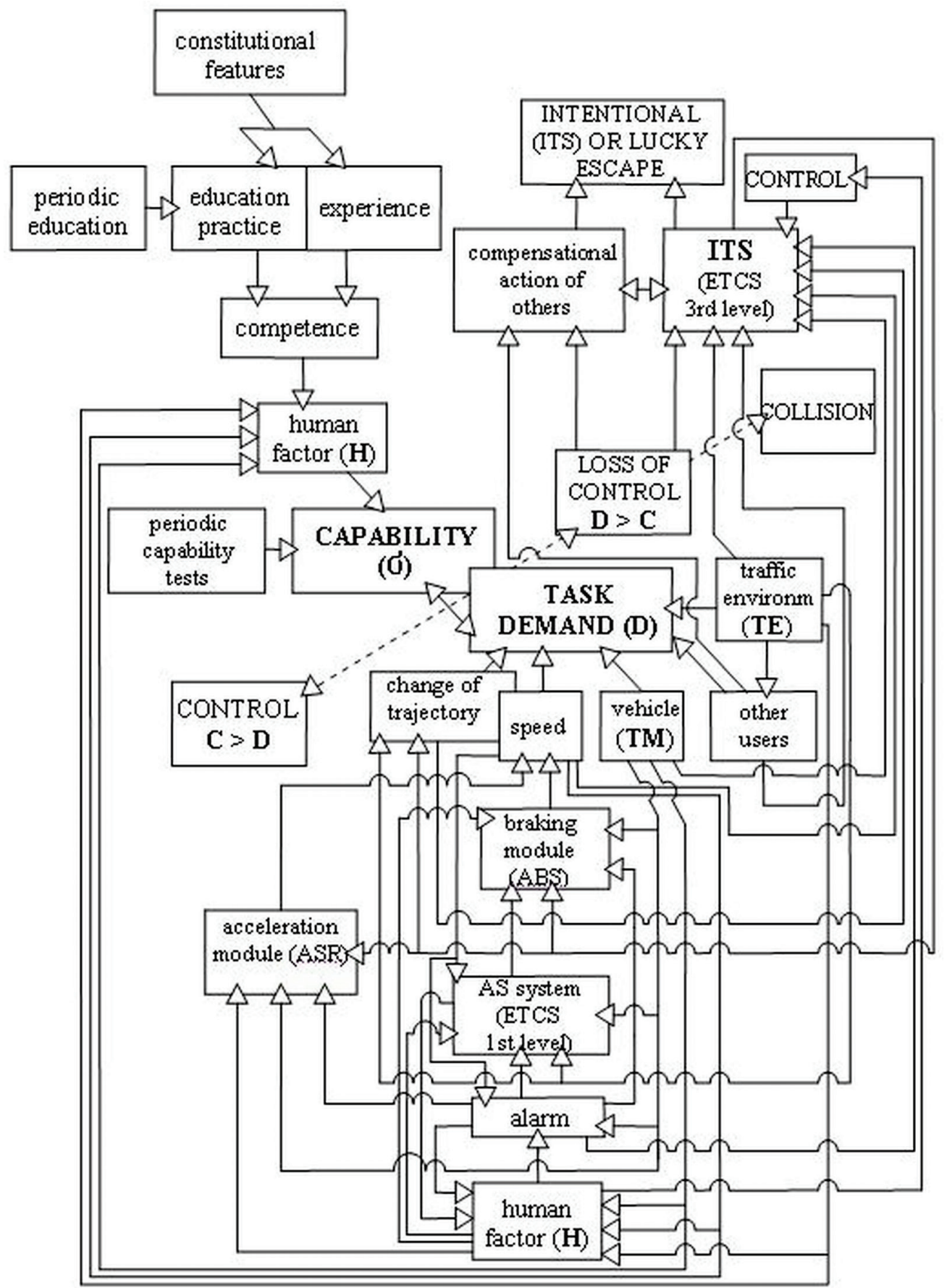

Figure 2 Dynamic open TCI model of "task demand - engine driver capability" interface in Croatia with the future development option (Basic Fuller TCI model [4] adapted and modified for rail traffic in Croatia [6])

The doctoral dissertation [6] has proven the correlation of the mean grade value $\bar{o}$ for the overall intensity of the psychophysical effort of engine drivers with the availability and accessibility of the commands to serve the AS system, as well as with the arrangement, accessibility and number of possible options of serving the alarm on the control panel and in the driver cab. This proves the well-foundedness of the hypothesis that inadequate design of the driver cab and the control panel may influence the difficulty of the driving task, i.e. the mental load of engine drivers. The ergonomic assessment $[6,7,8]$ points to the important factor of disturbance of engine drivers from the traffic environment in Croatia, "poor organization of traffic and big delays" and the dynamic disturbance factor "passenger care", both related to the problems of timetable. In the studies by Haramina et al. [11] from 2012 a dynamic timetable is proposed, and the adaptation of the timetable to the real condition in 
traffic was realized by means of the system based on fuzzy decision-making, with the aim of forecasting of the real time of retention of suburban trains at stops depending on the train occupancy and the number of passengers at stops. The traffic solution by Haramina et al. [11] as the system for assistance to engine drivers during work is the ergonomically justified intervention into the group of factors "traffic environment", which will result in lower mental workload and more humane work of the engine drivers.

The mentioned studies match the newer trends in studying the "human factor" in rail traffic. According to Wilson and Noriss from 2005 [12] and the guidelines of Rail Safety and Standards Board from Great Britain the actual priorities during scientific research that can be related to the safety and the group of factors "human factor" include, among others: evaluation of the mental load in engine drivers, and the design of the driver cab and the environment.

In this paper the constitutional factors from the group "human factor" are studied, which are important for the design of the driver cab, because of the possible influence of inadequate design on the difficulty of the driving task. A part of the traffic engineering staff and a part of the scientific community for the scientific field traffic and transport technology in Croatia share an opinion that the traffic engineers should not meddle in detail regarding the driver cab design. This is a completely wrong thinking with possible dangerous consequences. According to Woodson, W. E., Tillman, B. and Tillman, P. [13], for maximal acceptance of the users' requirements (engine drivers) it is important for the user (operator company) to be included during the design of the transport means in the earliest possible phase at the beginning of the development process, during setting of the system requirements. It is not sufficient to regulate [14] that the manual train air brake controller has to be located on the right side of the control panel, and the operating controller to control EMV (setting of the traction/braking force) on the left side, and that the positions of handles have to be according to UIC 612 standard. It is of utmost importance that the controllers for manual serving are ergonomically designed, whether they are multi-purpose ones (combination of frequently used commands of the accelerator, braking module and "dead-man" function), how far they are located on the control panel to the right or to the left in relation to the central symmetry axis, and how much to the front (from the engine driver), i.e. for which ranges of static anthropometric measures in the central $90 \%$ from the entire population of engine drivers.

\section{The required number of respondents to determine the range of normal and maximal arm reach}

According to Muftic et al. [10] the body segment lengths in the majority of people of normal body constitution as harmonic values with acceptable daviations result from the standing height $h$. The majority of the measured statical anthropometric measures in humans according to Tab. 1 are the values that are subject to normal distribution, so that for every studied anthropometric measure in a random sample of $n=50$ engine drivers from the entire population of $N=1,410$ engine drivers in Croatia it can be proven whether the random sample is also a sufficient one. According to Kovač-Striko, Fratrović and Ivanković [15] a sufficiently large sample is $n>30$ from any basic set of the expected mean $\mu$ and standard deviation $\sigma$. Thus, in designing new driver cabs, adapted to the entire population of $N$ engine drivers in Croatia, the ranges of characteristic anthropometric measures for normal and maximal arm rach need to be recognized. Considered in the layout of the driver cab and transversal plane of the engine driver, according to the instruction by Kroemer and Grandjean [16] $5 \%$ of the biggest and $5 \%$ of the smallest persons (in body dimensions referred to in the analysis) need to be excluded, in order to include the centiles that are between $5 \%$ and $95 \%$, thus for the approximately central $90 \%$ from the randomly selected and sufficient sample of $n$ respondents. In 1984 Taboršak defined the areas of normal and largest arm reach in three planes [17], according to Fig. 3. The presented results from the 1980s are not actual any more. Mean value of standing height for men in Croatia has increased.

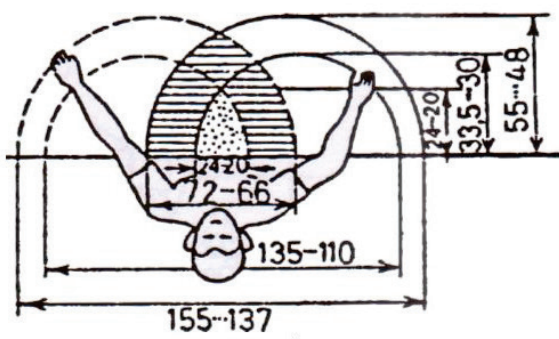

a)

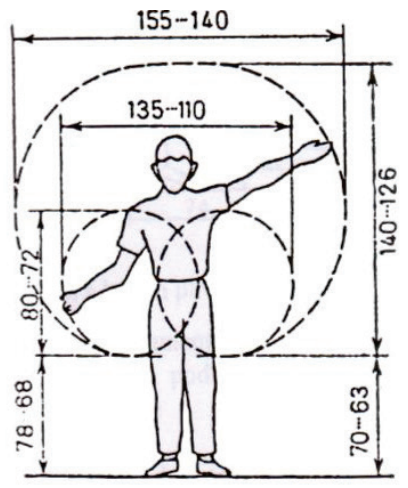

b)

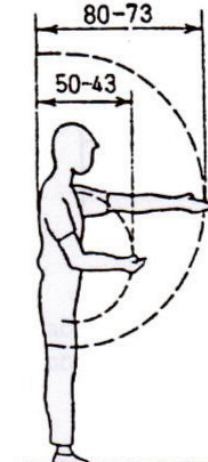

c)

Figure 3 Zones of normal and maximal arm reach [17]

The first symbol at elevation is for the male and the second one for the female gender, and the zones are for the planes: a) transversal plane, b) frontal plane, c) sagital plane. Tab. 1 contains the results of measuring statical anthropometric measures from 2012, important to determine the normal and maximal arm reach, on a random sample of 50 engine drivers. Statistical anthropometric measure arm length can be identified with 
a maximal arm reach in a horizontal position, if we ignore the folds of skin and extension in the joints. Anthropometric measures had been measured in the same period of day for all the respondents, but only for the left part of body of all the respondents. During the measuring digital scales and calibrated altimeter Tanita WB 3000 (accuracy Class 3), and moderate anthropometers Lafayette (accuracy Class 2), were used. The measured anthropometric measures have been rounded to integer centimetre.

Table 1 Static anthropometric measures in case of 50 male engine drivers from random sample significant for the control panel design in Croatia

\begin{tabular}{|c|c|c|c|c|c|c|c|c|}
\hline \multirow{2}{*}{$\begin{array}{c}\text { Resp. } \\
\text { No. }\end{array}$} & \multirow{2}{*}{$B M I$} & $m$ & $h$ & $h_{b r}$ & $h_{\check{s}}$ & $h_{n d r}$ & $h_{m d r}$ & $h_{\text {dir }}$ \\
\hline & & $\mathrm{kg}$ & $\mathrm{cm}$ & $\mathrm{cm}$ & $\mathrm{cm}$ & $\mathrm{cm}$ & $\mathrm{cm}$ & $\mathrm{cm}$ \\
\hline 1 & 28,4 & 94 & 182 & 46,0 & 20,0 & 44,0 & 78,0 & 90,0 \\
\hline 2 & 31,8 & 94 & 172 & 47,0 & 22,0 & 46,0 & 74,0 & 93,0 \\
\hline 3 & 24,9 & 90 & 190 & 46,0 & 22,0 & 46,0 & 75,0 & 96,0 \\
\hline 7 & 24,5 & 75 & 175 & 44,0 & 21,0 & 46,0 & 78,0 & 90,0 \\
\hline 8 & 30,0 & 105 & 187 & 46,0 & 20,0 & 47,0 & 80,0 & 92,0 \\
\hline 13 & 27,7 & 97 & 187 & 48,0 & 20,0 & 48,0 & 78,0 & 92,0 \\
\hline 15 & 29,1 & 103 & 188 & 47,0 & 22,0 & 46,0 & 78,0 & 93,0 \\
\hline 16 & 26,3 & 90 & 185 & 44,0 & 20,0 & 46,0 & 77,0 & 87,0 \\
\hline 17 & 27,5 & 92 & 183 & 51,0 & 20,0 & 46,0 & 81,0 & 90,0 \\
\hline 18 & 25,7 & 88 & 185 & 46,0 & 22,0 & 49,0 & 81,0 & 96,0 \\
\hline 19 & 29,0 & 94 & 180 & 44,0 & 21,0 & 46,0 & 75,0 & 87,0 \\
\hline 21 & 31,7 & 105 & 182 & 46,0 & 19,0 & 47,0 & 76,0 & 88,0 \\
\hline 22 & 29,2 & 100 & 185 & 47,0 & 21,0 & 45,0 & 75,0 & 89,0 \\
\hline 27 & 27,7 & 100 & 190 & 45,0 & 20,0 & 47,0 & 79,0 & 96,0 \\
\hline 28 & 29,9 & 98 & 181 & 47,0 & 21,0 & 46,0 & 77,0 & 96,0 \\
\hline 35 & 34,1 & 108 & 178 & 49,0 & 22,0 & 47,0 & 78,0 & 92,0 \\
\hline 41 & 32,4 & 105 & 180 & 48,0 & 22,0 & 48,0 & 80,0 & 96,0 \\
\hline 53 & 33,6 & 104 & 176 & 50,0 & 20,0 & 44,0 & 72,0 & 88,0 \\
\hline 57 & 30,4 & 93 & 175 & 48,0 & 20,0 & 45,0 & 75,0 & 89.0 \\
\hline 62 & 34.0 & 115 & 184 & 48.0 & 21.0 & 46.0 & 71.0 & 93.0 \\
\hline 63 & 20.5 & 65 & 178 & 43.0 & 20.0 & 46.0 & 75.0 & 88.0 \\
\hline 65 & 32.8 & 104 & 178 & 49.0 & 20.0 & 46.0 & 76.0 & 92.0 \\
\hline 66 & 23.7 & 70 & 172 & 46.0 & 21.0 & 43.0 & 72.0 & 85.0 \\
\hline 67 & 28.7 & 90 & 177 & 46.0 & 21.0 & 46.0 & 73.0 & 89.0 \\
\hline 70 & 24.8 & 82 & 182 & 47.0 & 20.0 & 44.0 & 78.0 & 86.0 \\
\hline 71 & 26,2 & 85 & 180 & 45,0 & 22,0 & 48,0 & 76,0 & 93,0 \\
\hline 72 & 30,6 & 97 & 178 & 48,0 & 20,0 & 43,0 & 76,0 & 89,0 \\
\hline 73 & 29,1 & 105 & 190 & 47,0 & 22,0 & 50,0 & 83,0 & 90,0 \\
\hline 75 & 26,0 & 76 & 171 & 41,0 & 20,0 & 41,0 & 73,0 & 84,0 \\
\hline 76 & 35,6 & 122 & 185 & 49,0 & 20,0 & 43,0 & 74,0 & 95,0 \\
\hline 77 & 33,4 & 118 & 188 & 50,0 & 22,0 & 48,0 & 78,0 & 95,0 \\
\hline 207 & 30,6 & 115 & 194 & 48,0 & 23,0 & 50,0 & 82,0 & 97,0 \\
\hline 208 & 29,0 & 97 & 183 & 45,0 & 23,0 & 50,0 & 78,0 & 96,0 \\
\hline 85 & 23,5 & 64 & 165 & 42,0 & 19,0 & 40,0 & 68,0 & 81,0 \\
\hline 100 & 30,3 & 96 & 178 & 44,0 & 21,0 & 46,0 & 76,0 & 86,0 \\
\hline 101 & 28,1 & 85 & 174 & 44,0 & 20,0 & 44,0 & 73,0 & 87,0 \\
\hline 102 & 24,6 & 85 & 186 & 40,0 & 20,0 & 49,0 & 81,0 & 92,0 \\
\hline 103 & 27,8 & 93 & 183 & 37,0 & 20,0 & 46,0 & 79,0 & 96,0 \\
\hline 104 & 22,9 & 70 & 175 & 42,0 & 19,0 & 43,0 & 72,0 & 84,0 \\
\hline 105 & 27,1 & 82 & 174 & 42,0 & 19,0 & 43,0 & 73,0 & 85,0 \\
\hline 106 & 41,7 & 138 & 182 & 35,0 & 20,0 & 49,0 & 77,0 & 98,0 \\
\hline 107 & 29,4 & 93 & 178 & 44,0 & 21,0 & 46,0 & 79,0 & 93,0 \\
\hline 108 & 28,5 & 105 & 192 & 51,0 & 21,0 & 47,0 & 81,0 & 92,0 \\
\hline 109 & 24.3 & 72 & 172 & 43.0 & 21.0 & 41.0 & 74.0 & 83.0 \\
\hline 110 & 27.8 & 90 & 180 & 44.0 & 20.0 & 47.0 & 78.0 & 96.0 \\
\hline 111 & 34.9 & 107 & 175 & 44.0 & 20.0 & 47.0 & 77.0 & 88.0 \\
\hline 112 & 27.4 & 84 & 175 & 42.0 & 19.0 & 42.0 & 72.0 & 88.0 \\
\hline 113 & 32.2 & 101 & 177 & 46.0 & 20.0 & 46.0 & 78.0 & 91.0 \\
\hline 114 & 27.8 & 90 & 180 & 46.0 & 20.0 & 45.0 & 78.0 & 91.0 \\
\hline 115 & 32.1 & 96 & 173 & 45.0 & 19.0 & 47.0 & 75.0 & 88.0 \\
\hline
\end{tabular}

Tab. 3, according to instruction by Kroemer and Grandjean [16], for every body dimension referred to by the analysis, presents the calculated and measured amounts of the ranges of anthropometric measures for the central $90 \%$ from the random sample, after having proven based on the comparison of deviation $\sigma_{\bar{h}_{i}}$ of arithmetic mean or mean value of individual anthropometric measure $h_{i}$ from the expected mean $\mu$ for the same anthropometric measure in the entire population, 
that the random sample of $n=50$ of engine drivers is sufficient, for all statical anthropometric measures apart from the length of hand.

The arithmetic mean or the mean value of individual anthropometric measure $\bar{h}_{i}$ for sample $n=50$ of engine drivers in Croatia from Table 1 is calculated according to Eq. (2).

$\bar{h}_{i}=\frac{h_{1}+h_{2}+\ldots h_{n}}{n}=\frac{1}{n} \cdot \sum_{i=1}^{n} h_{i}$

Standard deviation $\sigma_{h_{i}}$ of individual anthropometric measure $h_{i}$ in random sample $n=50$ of engine drivers from Tab. 1 has been calculated according to formula (3).

$$
\sigma_{h_{i}}=\sqrt[2]{\frac{1}{n-1} \cdot \sum_{i=1}^{n}\left(h_{i}-\bar{h}_{i}\right)^{2}}=\sqrt[2]{\frac{1}{n-1} \cdot \sum_{i=1}^{n} \Delta h^{2}}
$$

Deviation $\sigma_{\bar{h}_{i}}$ of arithmetic mean of individual anthropometric measure $\bar{h}_{i}$ in random sample of $n$ engine drivers from Table 1 in relation to the expected mean value of the anthropometric measure $\mu$ in the basic set of the entire population of $N=1,410$ engine drivers in Croatia, has been calculated according to Eq. (4).

$\sigma_{\overline{h i}}=\frac{\sigma_{h i}}{\sqrt[2]{n}} \cdot \sqrt[2]{\frac{N-n}{N-1}}$

The range of the measured anthropometric measures $\Delta h_{i}$ for the central $90 \%$ from Tab. 3 have been verified by the calculation using expressions (5) and (6) adopted from Kroemer and Grandjean [16], that combine centiles $c$, arithmetic mean $\bar{h}_{i}$ and the standard deviation $\sigma_{h_{i}}$ in the entire sample, for all the measured statical anthropometric measures from Table 1. Expressions (5) and (6) result in expression (7) for $\Delta h_{i 90 \%}$ as the calculated range of values of studied anthropometric measures in the central $90 \%$ of respondents from the sample.

$$
\begin{aligned}
& 5,0 \cdot c=\bar{h}_{i}-1,65 \cdot \sigma_{h_{i}} \\
& 95,0 \cdot c=\bar{h}_{i}+1,65 \cdot \sigma_{h_{i}} \\
& \Delta h_{i 90 \%}=5,0 \cdot c \div 95,0 \cdot c .
\end{aligned}
$$

Fifty engine drivers from the random and sufficient sample who operated all these types of locomotives and/or railcars are in the range from 28 to 52 years of age. The lengths of their body segments outside the balance seating position (hands, forearms and upper arms) for each one of them will not be ideal harmonic values that according to Tab. 2 can be calculated from the standing height $h$.

The comparison of results from Tabs. 1 and 3 confirms the deviation of the body segment lengths from the canon $h=8 h_{g}$, since in the ranges of different anthropometric measures for the central $90 \%$ from Tab. 2 not always the same engine drivers are included. Simplified, all engine drivers from the $5 \%$ of the tallest ones (respondents No. 207 and 108 from Tab. 1) do not necessarily have the lengths of arms that enter the $5 \%$ of the longest ones.

Table 2 Anthropometric values of a human as function of the standing height $h$ according to canon $h=8 h_{g}$ [10]

\begin{tabular}{|c|c|c|}
\hline Body segment & Symbol of length & Function \\
\hline arm & $h_{\mathrm{r}}$ & $=25 / 64 \cdot h$ \\
\hline forearm & $h_{\mathrm{p}}$ & $=h / 8$ \\
\hline upper arm & $h_{\mathrm{n}}$ & $=5 / 32 \cdot h$ \\
\hline hand & $h_{\check{\mathrm{s}}}$ & $=7 / 64 \cdot h$ \\
\hline
\end{tabular}

Tab. 1 shows that the anthropometric length of the hand $h_{\check{s}}$ in this value of random sample $n=50$ even in this measurement accuracy (rounding of the measured value $h_{\check{s}}$ to an integer $\mathrm{cm}$ ) does not behave completely according to the laws of normal distribution, because even six engine drivers have the smallest measured length of hand of $19 \mathrm{~cm}$, which prevents the rejection of the $5 \%$ shortest hand lengths. Therefore in Tab. 3 the range of the hand length for the central $90 \%$ from the random sample is relevant only on the basis of the calculation according to expressions (5), (6) and (7). However, the length of the hand is not the crucial anthropometric measure in dimensioning if the manual controller is located within the anthropometric measure $h_{\mathrm{ndr}}$ for normal arm reach in the central $90 \%$ of the respondents.

In all the other ranges of analyzed anthropometric measures from Tab. 3 the limits of calculated and measured ranges for the central $90 \%$ differ by a maximum of $1,5 \mathrm{~cm}$ for the anthropometric measure $h_{\mathrm{dir}}$ (reach of extended arm from the tip of the longest finger to the most protruding part of the back). The range of the anthropometric measure $h_{\mathrm{dir}}$ is not so important for the design of the driver cab itself, more important are the ranges of anthropometric measures $h_{\mathrm{ndr}}$ and $h_{\mathrm{mdr}}$. In nature the extreme value of anthropometric measure $h_{\text {dir }}$ outside the range of the amount for the central $90 \%$ can be compensated in a certain smaller amount by moving the seat from or towards the control panel, or by changing the seat back pitch.

Tab. 3 contains also the calculated values of the studied anthropometric measures according to harmonic expressions from Tab. 2 based on the canon $h=8 h_{g}$, for the average standing height of the entire sample $\bar{h}=180,4$ $\mathrm{cm}$. Tab. 3 shows that a large majority of respondents from the central $90 \%$ of the random sample has measured anthropometric measures of the analyzed body segments of the arm (apart from the hand) greater than the amount of the anthropometric measures calculated for the average standing height $\bar{h}=180,4$ by harmonic analysis. In circumstances when the majority of respondents from the random sample have anthropometric measures of the arm segments somewhat larger than the anthropometric measures of arms which would result from harmonic analysis, one can expect increased calculated amounts of lumbar moment $M_{1 y}$ at the level of vertebrae L4/L5 according to regression function $M_{1 y}=M_{1 v}(B M I)$ obtained based on the actually measured anthropometric measures. 
Table 3 Ranges of anthropometric measures $\Delta h$ for the entire randomly selected sample $n=50$ and $\Delta h_{90 \%}$ for the central $90 \%$ from the sample

\begin{tabular}{|c|c|c|c|c|}
\hline \multirow{2}{*}{$\begin{array}{c}\text { Anthropometric } \\
\text { measure }\end{array}$} & \multirow{2}{*}{$\begin{array}{c}\text { Symbol / measuring } \\
\text { unit }\end{array}$} & \multirow{2}{*}{ Remark } & \multicolumn{2}{|c|}{ Amount for } \\
\hline & & & $n=50$ & central $90 \%$ \\
\hline \multirow{6}{*}{$\begin{array}{l}h \text { - standing height in } \\
\text { balanced standing } \\
\text { posture }[10,16]\end{array}$} & $\bar{h} / \mathrm{cm}$ & calculated - Eq. (2) & 180,4 & 180,4 \\
\hline & $\Delta h / \mathrm{cm}$ & measured for $n=50-$ Tab. 1 & $165 \div 194$ & 1 \\
\hline & \multirow{2}{*}{$\Delta h_{90 \%} / \mathrm{cm}$} & measured for $n=46-$ Tab. 1 & 1 & $172 \div 190$ \\
\hline & & calculated - Eqs. (5), (6) and (7) & 1 & $170,2 \div 190,6$ \\
\hline & $\sigma_{h} / \mathrm{cm}$ & calculated - Eq. (3) & 6,2 & 5,2 \\
\hline & $\sigma_{\bar{h}} / \mathrm{cm}$ & calculated - Eq. (4) & 0,86 & 0,75 \\
\hline \multirow{6}{*}{$\begin{array}{l}h_{b r}-\text { shoulder width } \\
{[16], \text { biacromial range }} \\
\text { in the area of shoulder } \\
\text { joints }\end{array}$} & $\bar{h}_{\mathrm{br}} / \mathrm{cm}$ & calculated - Eq. (2) & 45,5 & 45,6 \\
\hline & $\Delta h_{\mathrm{br}} / \mathrm{cm}$ & measured for $n=50-$ Tab. 1 & $35,0 \div 51,0$ & I \\
\hline & \multirow{2}{*}{$\Delta h_{\mathrm{br} 90 \%} / \mathrm{cm}$} & measured for $n=46-$ Tab. 1 & 1 & $41,0 \div 50,0$ \\
\hline & & Calculated - Eqs. (5), (6) and (7) & 1 & $40,5 \div 50,5$ \\
\hline & $\sigma_{h_{\mathrm{br}}} / \mathrm{cm}$ & calculated - Eq. (3) & 3,0 & 2,4 \\
\hline & $\sigma_{\overline{h_{\mathrm{br}}}} / \mathrm{cm}$ & calculated - Eq. (4) & 0,42 & 0,35 \\
\hline \multirow{7}{*}{$\begin{array}{l}h_{n d r} \text { - normal arm } \\
\text { reach or working } \\
\text { distance [16], from } \\
\text { elbow to the tip of the } \\
\text { longest finger }\end{array}$} & $\bar{h}_{\mathrm{ndr}} / \mathrm{cm}$ & calculated - Eq. (2) & 45,8 & 45,8 \\
\hline & $\Delta h_{\mathrm{ndr}} / \mathrm{cm}$ & measured for $n=50-$ Tab. 1 & $41,0 \div 50,0$ & 1 \\
\hline & \multirow{2}{*}{$\Delta h_{\mathrm{ndr} 90 \%} / \mathrm{cm}$} & measured for $n=45-$ Tab. 1 & 1 & $42,0 \div 49,0$ \\
\hline & & Calculated - Eqs. (5), (6) and (7) & 1 & $42,0 \div 49,6$ \\
\hline & $\left(h_{\mathrm{p}}+h_{\check{\mathrm{s}}}\right) / \mathrm{cm}$ & calculated based on $h=8 h_{g}-$ Table 2 & & \\
\hline & $\sigma_{h_{\mathrm{ndr}}} / \mathrm{cm}$ & calculated - Eq. (3) & 2,3 & 1,9 \\
\hline & $\sigma_{\bar{h}_{\text {ndr }}} / \mathrm{cm}$ & calculated - Eq. (4) & 0,32 & 0,28 \\
\hline \multirow{7}{*}{$\begin{array}{l}h_{m d r}-\text { maximal arm } \\
\text { reach or length of } \\
\text { reach [16], from } \\
\text { shoulder joint to the } \\
\text { tip of the longest } \\
\text { finger }\end{array}$} & $\bar{h}_{\mathrm{mdr}} / \mathrm{cm}$ & calculated - Eq. (2) & 76,5 & 76,5 \\
\hline & $\Delta h_{\mathrm{mdr}} / \mathrm{cm}$ & measured for $n=50-$ Tab. 1 & $68,0 \div 83,0$ & 1 \\
\hline & \multirow{2}{*}{$\Delta h_{\mathrm{mdr} 90} \% / \mathrm{cm}$} & measured for $n=46-$ Tab. 1 & 1 & $72,0 \div 81,0$ \\
\hline & & calculated - Eqs. (5), (6) and (7) & 1 & $71,3 \div 81,7$ \\
\hline & $h_{\mathrm{r}} / \mathrm{cm}$ & calculated based on $h=8 \cdot h_{g}-$ Tab. 2 & & \\
\hline & $\sigma_{h_{\mathrm{mdr}}} / \mathrm{cm}$ & calculated - Eq. (3) & 3,2 & 2,6 \\
\hline & $\sigma_{\bar{h}_{\mathrm{mdr}}} / \mathrm{cm}$ & calculated - Eq. (4) & 0,45 & 0,38 \\
\hline \multirow{7}{*}{$\begin{array}{l}h_{\check{s}}-\text { hand length, } \\
\text { from wrist to the tip of } \\
\text { the longest finger }\end{array}$} & $\bar{h}_{\check{s}} / \mathrm{cm}$ & calculated - Eq. (2) & 20,6 & 20,6 \\
\hline & $\Delta h_{\check{\mathrm{s}}} / \mathrm{cm}$ & measured for $n=50-$ Tab. 1 & $19,0 \div 23,0$ & 1 \\
\hline & \multirow{2}{*}{$\Delta h_{\check{s} 90 \%} / \mathrm{cm}$} & measured for $n=42-$ Tab. 1 & & $20,0 \div 22,0$ \\
\hline & & calculated - Eq. (5), (6) and (7) & 1 & $18,8 \div 22,3$ \\
\hline & $h_{\check{s}} / \mathrm{cm}$ & calculated based on $h=8 h_{g}-$ Tab. 2 & & \\
\hline & $\sigma_{h_{\breve{s}}} / \mathrm{cm}$ & calculated - Eq. (3) & 1,1 & 0,9 \\
\hline & $\sigma_{\bar{h}_{\check{\mathrm{s}}}} / \mathrm{cm}$ & calculated - Eq. (4) & 0,15 & 0,13 \\
\hline \multirow{6}{*}{$\begin{array}{l}h_{\mathrm{dir}}-\text { reach of } \\
\text { extended arm [10], } \\
\text { from the tip of the } \\
\text { longest finger to the } \\
\text { most protruding part } \\
\text { of the back }\end{array}$} & $\bar{h}_{\text {dir }} / \mathrm{cm}$ & calculated - Eq. (2) & 90,6 & 90,7 \\
\hline & $\Delta h_{\mathrm{dir}} / \mathrm{cm}$ & measured for $n=50-$ Tab. 1 & $81,0 \div 98,0$ & 1 \\
\hline & \multirow{2}{*}{$\Delta h_{\mathrm{dir} 90 \%} / \mathrm{cm}$} & measured for $n=46-$ Tab. 1 & & $84,0 \div 96,0$ \\
\hline & & calculated - Eqs. (5), (6) and (7) & 1 & $83,8 \div 97,5$ \\
\hline & $\sigma_{h_{\mathrm{dir}}} / \mathrm{cm}$ & calculated - Eq. (3) & 4,1 & 3,6 \\
\hline & $\sigma_{\bar{h}_{\text {dir }}} / \mathrm{cm}$ & calculated - Eq. (4) & 0,60 & 0,52 \\
\hline
\end{tabular}

\section{Functional dependence of the measured lumbar moment $M_{1 y}$ on body mass index $B M I$}

Knowing the standing height $h$ and body mass $m$, by using Donskij-Zacijorskij method [18] it is possible to calculate the amounts of single segmental masses $m_{i}$ for hands, forearms, and upper arms in the respondents from Tab. 1, using the regression Eq. (8) and with determined regression factors $B_{0}, B_{1}$ and $B_{2}$.

$m_{i}=B_{0}+B_{1} \cdot m+B_{2} \cdot h(\mathrm{~kg})$
Table 4 Mass centres in the percentage of the function of the body segment length [19]

\begin{tabular}{|l|c|}
\hline \multicolumn{1}{|c|}{ Body segment } & Distance (\%)* \\
\hline Head and neck & 50,02 \\
\hline Upper torso & 50,66 \\
\hline Middle torso & 45,02 \\
\hline Lower torso & 59,59 \\
\hline Hand & 36,91 \\
\hline Thigh & 45,49 \\
\hline Lower leg & 40,49 \\
\hline Foot & 44,14 \\
\hline Upper arm & 44,98 \\
\hline Forearm & 42,74 \\
\hline
\end{tabular}


The positions of mass centres $m_{i}$ are calculated according to Tab. 4, measured from the upper border of the body segments.

Body segment gravities $F_{\text {gzi }}$ have been calculated according to Eq. (9), and the amounts of lumbar moments $M_{1 y}$ according to Eq. (10) have been obtained by the reduction of all the gravities $F_{\text {gzi }}$ from segmental masses $m_{i}$ into the origin of the coordinate system $x y$ in Fig. 4.

$$
\begin{aligned}
& F_{g_{z_{i}}}=m_{i} \cdot 9,81 \\
& M_{l y}=\sum_{i=1}^{n} F_{\mathrm{gz}_{i}} \cdot x_{i} .
\end{aligned}
$$

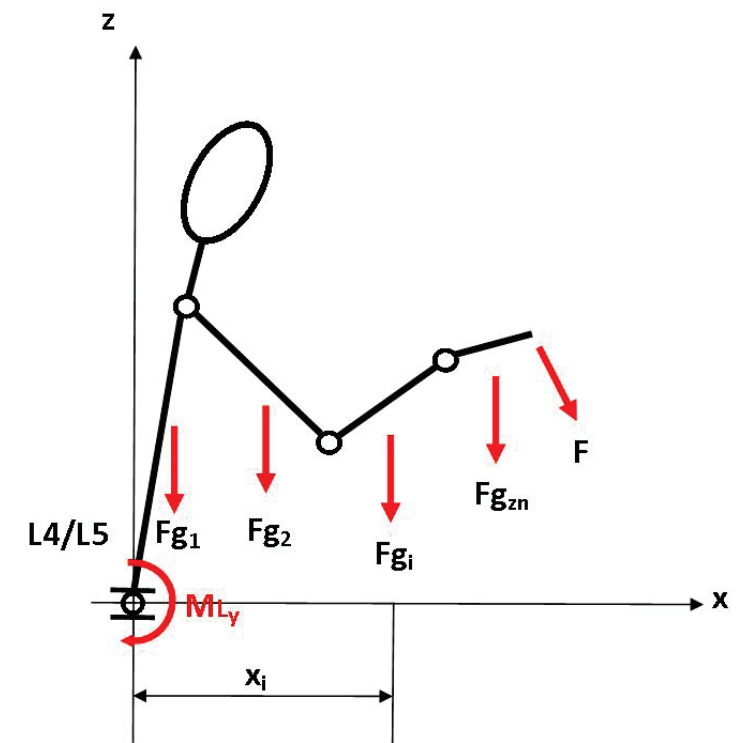

Figure 4 Two-dimensional stick model of the respondent in sagittal plane [20]

In compliance with the considerations of Mairiaux et al. [21], or Muftic et al. [10], the origin of the coordinate system xy represents also the point of reduction L4/L5 of the lumbar moment $M_{1 y}$ to the level between the fourth (penultimate) and fifth (last) lumbar vertebra in the mobile part of the spine viewed from above downwards.

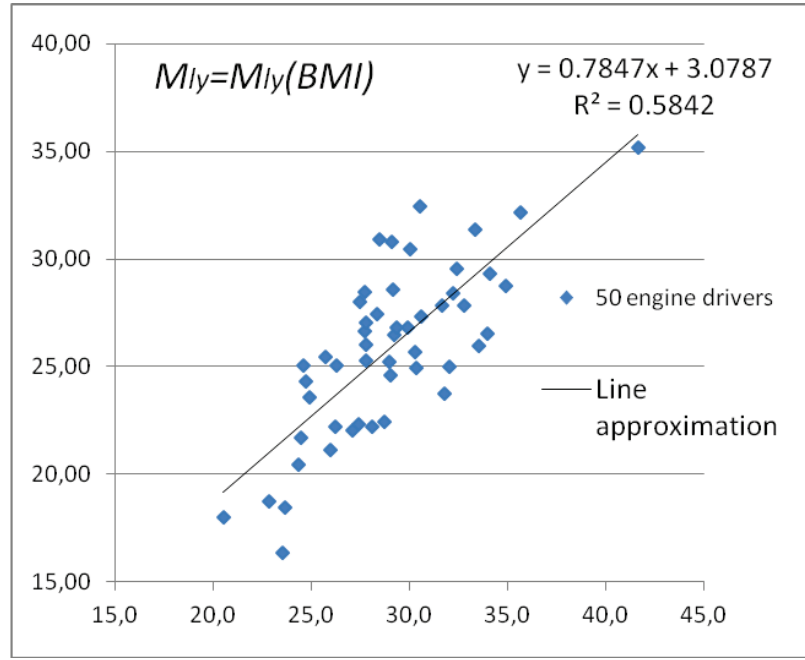

Figure 5 Regression function $M_{l y}=M_{l y}(B M I)$ based on the actually measured statical anthropometric measures from the random and sufficient sample $n=50$
Lumbar moment $M_{1 y}$ according to regression function (11) from the diagram in Fig. 5 has an acceptable correlation dependence $M_{1 y}=M_{1 y}(B M I)$ of medium strength, with correlation coefficient $R=0,764$.

$M_{1 y}=0,7847 \cdot B M I+3,0787$.

Regression function (11) refers to the stick biomechanical 2D model of an engine driver in sagittal plane according to Fig. 6, in the least favourable hypothetical static equilibrium working position, with both arms horizontally extended in the zone of maximal reach.

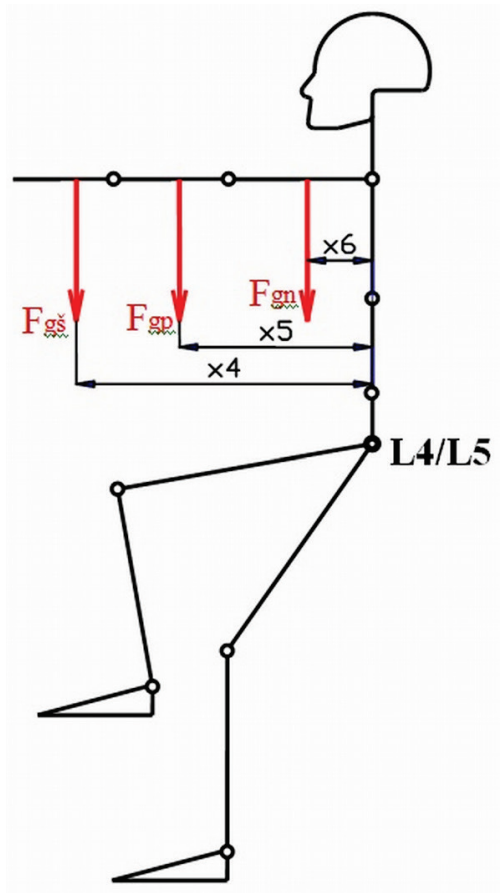

Figure 6 Stick biomechanical 2D model of an engine driver in sagittal plane, in the least favourable hypothetical static equilibrium working position, with arms horizontally extended in the zone of maximal reach [22]

For the same respondents from the random and sufficient sample $n=50$, when the body segment lengths of arms have been calculated from the standing height $h$ using harmonic analysis by Muftić an Zerderbauer [6, 10], the regression function (12) was obtained with strong correlation dependence $M_{1 y}=M_{1 y}(B M I)$, with correlation coefficient $R=0,806$.

$M_{1 y}=0,7813 \cdot B M I+1,0229$.

\section{Discussion}

The ranges of static anthropometric measures from Tab. 3 for the central $90 \%$ from the random sample need to be used when designing the dimensions of the control panels and driver cabs for the locomotives and/or railcars in Croatia, so that all the frequently used commands for manual serving are located mainly within the range of the normal arm reach.

After that, when employing new engine drivers, it is desirable that their static anthropometric measures 
important to determine the normal and maximal arm reach are within the range for the central $90 \%$ according to Tab. 3, calculated based on measuring the static anthropometric measures in $n=50$ engine drivers from the sufficient and random sample. The calculated and/or measured ranges of normal and maximal arm reach in Tab. 3 based on the actually measured anthropometric measures from Table 1 are of slightly bigger amounts in relation to normal and maximal arm reaches calculated according to canon $h=8 h_{g}$ from the standing height $h$, using harmonic numbers from Tab. 2 based on harmonic analysis by Muftić and Zerderbauer.

Also, in assessing the physical effort of engine drivers in the hypothetically least favourable working position according to Fig. 6 , and in interaction with the increased body mass $m$ in relation to the standing height $h$, it is necessary to use the regression function $M_{1 y}=M_{1 y}(B M I)$ according to Eq. (11), obtained based on the actually measured static anthropometric measures in $n$ $=50$ engine drivers from the random and sufficient sample, since it gives more accurate i.e. by 6,8 to $10 \%$ larger amounts of lumbar moments $M_{1 y}$, in relation to the amounts $M_{1 y}$ obtained by means of regression function (11) based on the harmonic analysis by Muftic and Zerderbauer.

Larger ranges of the calculated and/or measured anthropometric measures for the central $90 \%$ of the population of engine drivers in Croatia according to Tab. 3 in relation to the amounts obtained from the standing height $h$ by means of harmonic analysis according to Muftić and Zerderbauer, can be explained by different body constitutions of single engine drivers, influenced by phenotype variations during the years, but also with variations of the standing heights $h$ of individual engine drivers in different canons of the head height $h_{g}$ in relation to canon $h=8 \cdot h_{g}$.

\section{Conclusion}

The carried out measurements and calculations prove that the random sample of $n=50$ engine drivers is sufficient, so that the obtained results for the ranges of anthropometric measures in the central $90 \%$ refer to the entire population of engine drivers in Croatia, regarding the condition at the beginning of 2012. The paper presents how the physical load of engine drivers in the static seating working position expressed through the amounts of lumbar moment $M_{1 y}=M_{1 y}(B M I)$ at the level of vertebra L4/L5 can be intensively affected by the design of the control panel (driver cab), regarding the poor organization of frequently used commands in maximal arm reach. The results of these studies need to be recognized while designing the driver cabs and the control panels of locomotives and/or railcars in Croatia, as well as during recruitment of new employees. Since the anthropometric measures of engine drivers belong to the constitutional factors from the group "human factor", in circumstances when the design of the control panel and the arrangement of the frequently used commands on the control panel are not adapted to the prevalently normal arm reach for the central $90 \%$ of engine drivers from the entire population, there is increase in the difficulty of the driving task, according to the open dynamic TCI model "task demand- driver capability" according to Fuller. As long as the human (engine driver) in Croatia is present in the driver cab, and serves the commands with arms and/or legs, it is necessary to respect immediately during design of the driver cab and the control panel the interaction of the factors of the working environment in the driver cab with the "human factors" for the target population of engine drivers.

\section{References}

[1] Michon, J. A. A critical review of driver behavior models: What do we now, what should we do? // Human Behavior and Traffic Safety / Evans, L. and Schwing, R. C. New York: Plenum Press, 1985, pp. 485-520.

[2] Näätänen, R.; Summala, H. Road-user behavior and traffic accidents. Amsterdam, New York: North-Holland Publishing Company / Elsevier, 1976.

[3] Taylor, D. H. Drivers' galvanic skin response and the risk of accident. // Ergonomics. 7, 4(1964), pp. 439-451.

[4] Fuller, R. Towards a general theory of driver behaviour. // Accident Analysis and prevention. 37, 3(2005), pp. 461472.

[5] Rumar, K. The human factors in road safety. // XI ARRB Conference/Australian Road Researc Board Proceedings. 11, 1(1982), Melbourne. 1982. pp. 65-78.

[6] Sumpor, D. Metodologija ergonomske prosudbe tehnološkoga prijevoza željeznicom. (Methodology of Ergonomic Assessment of the Rail Transport Technological Process.) Doktorska disertacija. Zagreb: Sveučilište u Zagrebu, Fakultet prometnih znanosti, 2012.

[7] Sumpor, D.; Toš, Z.; Ivanković, B. The System of ErgoAssessment Factors of The Locomotive Drivers Working Environment. // Proceedings of Third International Conference on Rail Human Factors/Lille, 2009. cd. 8 p.

[8] Sumpor, D.; Jurum-Kipke, J.; Petrović, D. ErgoAssessment of Locomotive Drivers' Traffic Environment. // PROMET - Traffic \& Transportation. 22, 6(2010), pp. 439448

[9] Ostan, I.; Poljšak, B.; Podovšovnik Axelsson, E. Motivations for Healthy Lifestyle in Railroad Employees. // PROMET - Traffic \& Transportation. 24, 1(2012), pp. 4552.

[10] Muftić, O.; Milčić, D. Ergonomija u sigurnosti. (Ergonomics in Safety.) Zagreb: Iproz, 1999.

[11] Haramina, H.; Mlinarić, T. J.; Mihaljević, B. Model of Fuzzy Inference System for Forecasting Dwell Time Required by Commuter Trains at Stops. // Tehnicki vjesnik/Technical Gazette. 19, 2(2012), pp. 281-286.

[12] Wilson, J. R.; Norris, B. J. Rail human factors: Past, present and Future. // Applied Ergonomics. 35, (2005), pp. 649660

[13] Woodson, W. E.; Tillman, B.; Tillman, P. Human Factors Design Handbook. $2^{\text {nd }}$ ed. New York: McGraw-Hill, Inc., 1992.

[14] Juretić, S. et al. Elektromotorni vlak za gradsko-prigradski promet, Specifikacija tehničkih zahtjeva za novi EMV. Zagreb: HŽ putnički prijevoz, 2009.

[15] Kovač-Striko, E.; Fratrović, T.; Ivanković, B. Vjerojatnost i statistika s primjerima iz tehnologije prometa (Probability and Statistics with Examples from the Transport Technology.) Zagreb: Sveučilište u Zagrebu, Fakultet prometnih znanosti, 2008.

[16] Kroemer, K. H. E.; Grandjean, E. Prilagođavanje rada čovjeku. (Original: Fitting the Task to the Human), Jastrebarsko: Naklada Slap, 2000.

[17] Taboršak, D. Ergonomija. // Tehnička enciklopedija Jugoslavenskog Leksikografskog zavoda, Zagreb: JLZ, sv. 5. 1976. pp. 349-352. 
[18] Donskij, D. D.; Zacijorskij, V. M. Biomehanika. Moskva: Izdateljstvo Fizkultura i sport, 1979.

[19] Milčić, D.; Muftić, O.; Ljubišić, M. Metoda utvrđivanja promjene trbušnog tlaka za čučanj i povratak u početni položaj. // Safety - Journal for the Safety in the Work Organisation and Living Environment. 41, 1(1999), pp. 112.

[20] Jurum-Kipke, J.; Baksa, S.; Sumpor, D. Implementation of Ergonomic Judgement of the Passenger Workload in Virtual Aircraft Cabin Space.//Proceedings of International Scientific Conference "Science and Traffic Development ZIRP 07"/ur. Ivaković, Č. Zagreb: University of Zagreb, Faculty of Transport and Traffic Sciences, 28 and 29 March 2007. Invited lecture.

[21] Mairiaux, Ph.; Davis, D. R.; Stubbs, D. A.; Baty, D. Relation between intra-abdominal pressure and lumbar moments when lifting weights in erect posture. // Ergonomics. 27, 8(1984), pp. 883-894.

[22] Sumpor, D. Multipliciranje čimbenika ergoprosudbe sustava čovjek - okoliš u vodnom prometu. (Multiplying of Ergo-assessment Factors in the "humans - environment" system in Water Transport.) Znanstveni magistarski rad. Zagreb: Sveučilište u Zagrebu, Fakultet prometnih znanosti, 2009.

\section{Authors' addresses}

\section{Davor Sumpor, Ph.D.}

University of Zagreb

Faculty of Transport and Traffic Sciences

Vukelićeva 4, 10000 Zagreb, Croatia

E-mail: davor.sumpor@fpz.hr

Prof. Emeritus Dragutin Taboršak, Ph.D.

Vrhovčev vijenac 68, 10000 Zagreb, Croatia

E-mail: dragutin.taborsak@fsb.hr

Prof. Jasna Jurum-Kipke, Ph.D.

Klaićeva 11A, 10000 Zagreb, Croatia

E-mail: jurumj@gmail.com 